Geochemical Journal, Vol. 16, pp. 99 to 105,1982

\title{
The isotopic composition of carbonate carbon from deep-sea basalts
}

\author{
HANS-W. HubBERTEN * \\ Institut für Petrographie und Geochemie der Universität (TH) \\ Karlsruhe, Kaiserstrasse 12, D-7500 Karlsruhe, FRG.
}

(Received October 2, 1981: Accepted December 28, 1981)

\begin{abstract}
Oceanic basalts are often altered by circulating seawater. During this process carbonates are formed frequently as veinlets and crystal aggregates. Additionally hydrothermal carbonate is found occasionally.

The isotopic composition of secondary and possibly primary carbonates has been investigated for 75 samples from Hole 418 A, a $550 \mathrm{~m}$ long basalt sequence drilled during DSDP Legs 52 and 53 to the south of the Bermuda Rise, in the Atlantic Ocean. Isotope ratios of secondary carbonates, carbonate rich basalts and some of the so called "fresh" basalts have values typical for marine carbonates, i.e., $\delta^{13} \mathrm{C}+2.8$ to $2.3 \%$ vs. PDB. Isotope ratios of samples with small carbonate content fall in the range of primary magmatic carbon, i.e., $\delta^{13} \mathrm{C}-4$ to $-8 \%$.

The carbon isotope composition of carbonates in oceanic basalts is therefore constituted by an overprinting of seawater-derived secondary carbonates on traces of primary carbonate carbon.
\end{abstract}

\section{INTRODUCTION}

Carbon occurs in basaltic rocks in different forms: as reduced carbon, $\mathrm{CO}_{2}$ in inclusions and as carbonate which can be present in basaltic rocks in amounts of up to thousands of ppm (HoEFs, 1965).

Isotopic investigations of carbonate carbon in basaltic rocks are rare, compared with carbon isotope investigations for other igneous rocks such as carbonatites. The isotope ratios of carbonate carbon in basaltic rocks which have been published vary in a broad range from +3.7 to $-25 \%$ vs. PDB (O'NeIL et al., 1970; HoEFs, 1973; RÖSLER et al., 1977; JAVOY and FouILlaC, 1980). These results are much scattered from the isotope composition of magmatic carbon in carbonatites, volcanic $\mathrm{CO}_{2}$ gases and $\mathrm{CO}_{2}$ in inclusions which ranges from -4 to $-8 \%$ (TAYlor et al., 1967; DeINes, 1970, Pineau et al., 1976; Puchelt and HubBerten, 1980). Because of geological and petrological arguments that favor deep-seated origin and because of balance calculations it is assumed that primary carbon will isotopically fall in this range (PINEAU et al., 1976).
If an isotopic composition of -4 to $-8 \%$ is assumed for primary carbonate carbon, the above mentioned widespread values must be due to an alteration of the isotope composition. This alteration can be produced mainly by three different processes:

a) Isotopic fractionation due to a partial degassing during the ascent and cooling of magma (PINEAu et al., 1976).

b) Alteration of the primary isotopic composition due to an isotopic exchange with carbonate species of different isotopic composition.

c) Overprinting of the primary carbon isotope ratio by the formation of secondary carbonates from low temperature solutions in fractures and vesicles.

Investigations on oceanic basalts which have been cored during various cruises of the $D / V$ Glomar Challenger (Deep Sea Drilling Project) revealed that circulating seawater plays an important role in the alteration processes of the crustal rocks. Besides smectites, zeolites, FeMin-hydroxides and sulfides, various carbonates occur as secondary minerals in the altered parts as vesicle fillings and veins with up to centimeter size.

* Present adress: Inst. de Geol., Univ. Autonoma de Nuevo Leon, Apdo. Postal 104, 67700 Linares, Mexico. 
The working hypotheses were tested by analyzing possibly different carbonate carbon species in carbonate aggregates, carbonate rich basalts and "fresh" basalts with a carbonate content of less than $0.3 \%$, from a $550 \mathrm{~m}$ long basaltic sequence cored during Legs 52 and 53 in the Bermuda Rise region of the Atlantic Ocean.

\section{LOCALITY AND SAMPLING}

Figure 1 shows a map of the Bermuda Rise with the various holes which have been drilled during Legs 51 - 53 of the DSDP (November, 1976 to April, 1977).

The Bermuda Rise is a broad topographic feature about $2,000 \mathrm{~km}$ long and $1,000 \mathrm{~km}$ wide with a relief of about $1.3 \mathrm{~km}$. The material for this investigation came from Hole $418 \mathrm{~A}$ which is located at the southern end of the Bermuda
Rise at $25^{\circ} 02,10^{\prime} \mathrm{N}, 68^{\circ} 03,44^{\prime} \mathrm{W}$ in a water depth of $5,511 \mathrm{~m}$. The sediment cover in this area is about $320 \mathrm{~m}$ thick overlying a basaltic basement of Cretaceous age. The oceanic crust consists mainly of pillow basalts and pillow breccia, minor massive basalts and microdolerites which are cut by dykes in deeper levels of the hole. The basalts are almost exclusively plagioclase phyric with subordinate and variable amounts of clinopyroxene and olivine phenocrysts, and rare microphenocrysts of spinel (cf. Flower et al., 1980; RoBINSON et al., 1980). Chemically they are classified as K-poor olivine tholeiite and show only little variation throughout the whole cored sequence (EMMERMANN and PuChelt, 1980).

Most of the basalts appear to be quite fresh. Alteration marked by presence of smectites is locally intense in glassy margins. Secondary carbonates as infillings of veins and vesicles, and

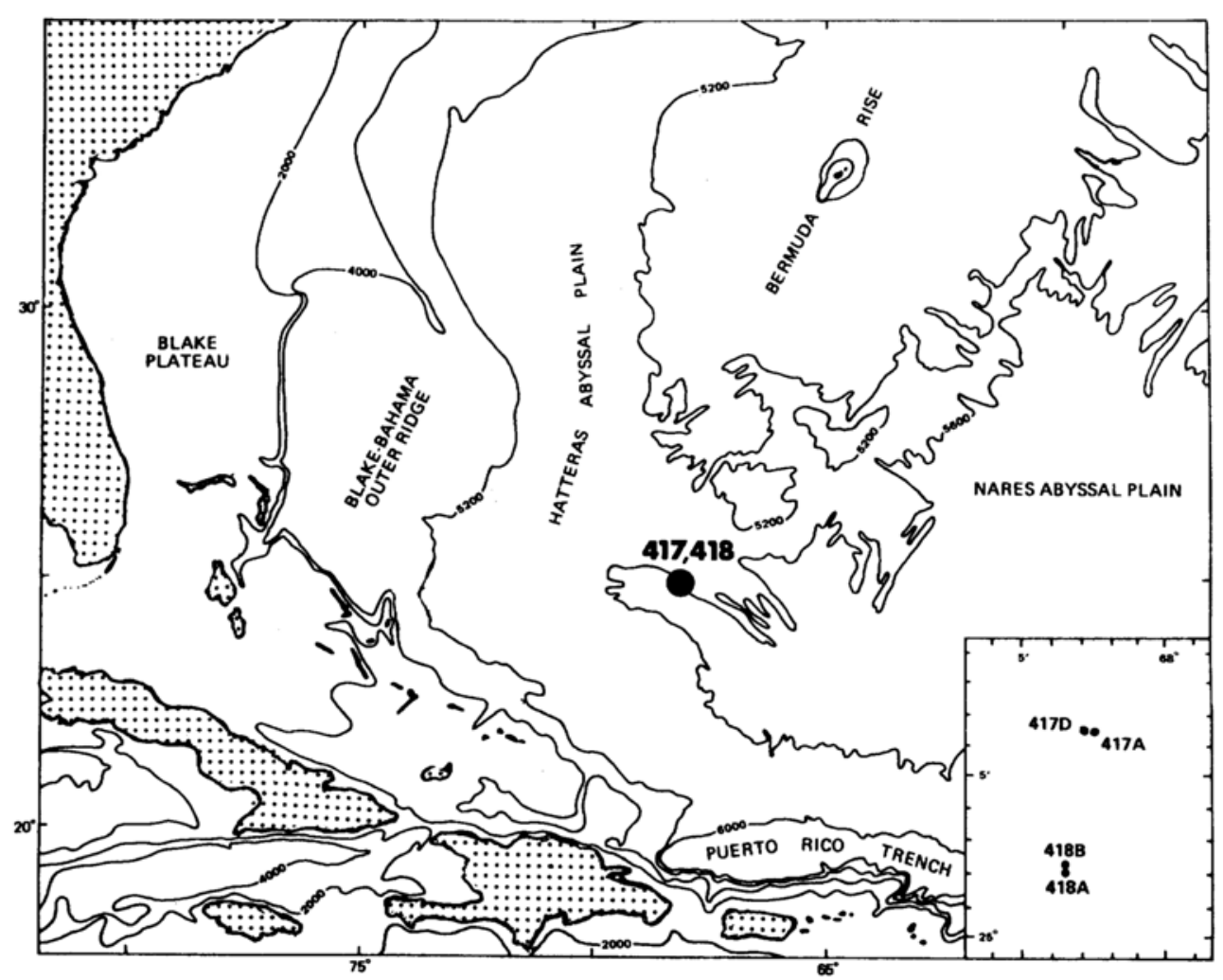

Fig. 1. Map of the Bermuda Rise showing positions of the various Holes drilled during DSDP Legs 51-53. 
as groundmass replacement are common (HumpHris et al., 1980). The secondary carbonates mainly consists of calcite and sometimes build up crystals 5 to $10 \mathrm{~mm}$ in length.

$30 \mathrm{cc}$ mini-core rock samples were collected on board ship. On one hand, "fresh" samples were collected covering the whole cored sequence; on the other hand particularly carbonate rich samples, as shown by veins or crystal aggregates have been chosen.

\section{Analytical Techniques}

Wherever possible pure carbonates from veins or crystal aggregates were hand picked before grinding. The samples were then ground in an agate mill to finer than 200 mesh.

The carbonate content was determined for all samples by thermal volatilization and electrochemical determination using an automatic carbon analyzer (Ströhlein Coulomat 701). The precision of the measurements is better than $\pm 5 \%$. The preparation for the carbon and oxygen isotope determinations was done according to the method described by MC'CrEA (1950) by disintegrating the carbonates with $100 \%$ phosphoric acid. The measurements were carried out on a VG-Micromass $602 \mathrm{C}$ gas-masspectrometer, the total error of the measurements is less than $\pm 0.2 \%$. The results were corrected after CRAIG (1953) and are given in the usual $\delta$ - form relative to the PDB standard.

\section{RESULTS}

The carbon and oxygen isotope ratios as well as the $\mathrm{CO}_{2}$ content of the samples are given in Table 1 and are shown as a function of depth in Fig. 2.

The carbon isotope data for all separated carbonates, for all carbonate rich basalts, and for part of the "fresh" basalts range between +2.8 and $-2.3 \%$ and lie therefore within the field of normal marine carbonates. Two samples of the overlying sedimentary sequence show typical values for marine carbonates $(-0.2$ and $+1.6 \%$ ). Some "fresh" basalt samples show lighter carbon isotope values $(-3.3$ to $-8.0 \% 0$ ) and reach the range of primary magmatic carbon. The oxygen isotope ratios lie also mostly in the range which is typical for marine carbonates of Cretaceous age ( -2 to $-7 \%$; KEITH and WEBER, 1964).

In some of the samples which are depleted in ${ }^{13} \mathrm{C}$, the oxygen isotope ratios are also shifted to lighter values but they never reach the range which is typical for carbonates formed at high temperatures ( -20 to $-25 \%$ (PDB); TAYLOR et al., 1967).

No systematic variation is observed in either $\delta^{13} \mathrm{C}$ or $\delta^{18} \mathrm{O}$ - values in relation to the depth.

\section{Discussion}

At first sight, it seems as if practically all

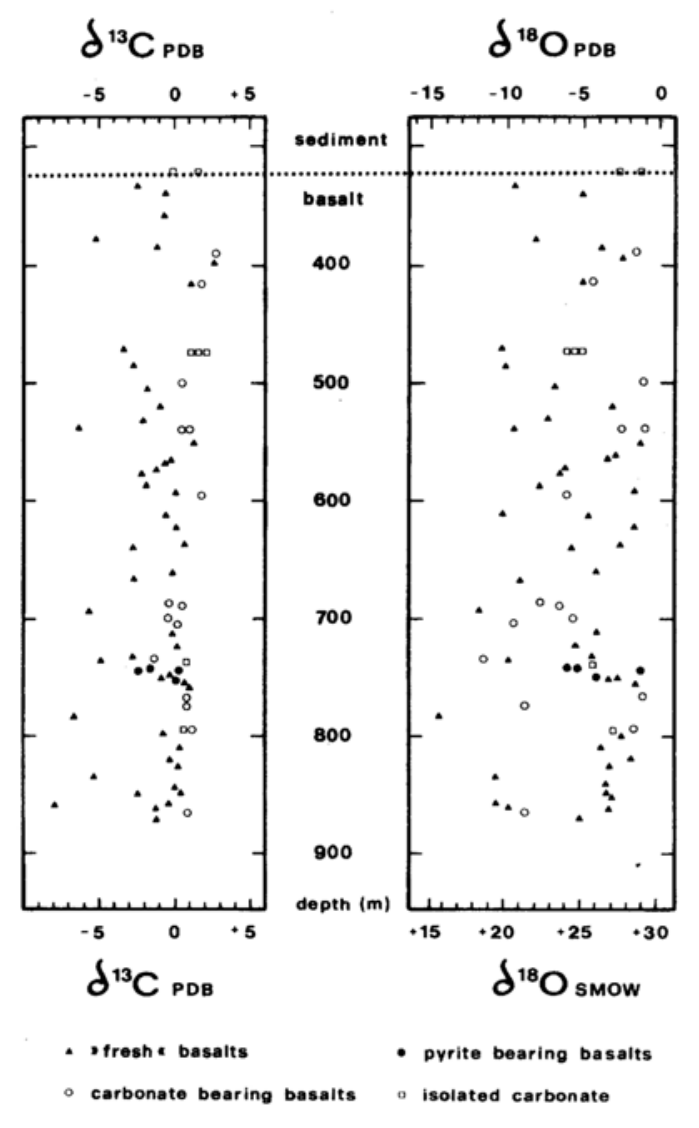

Fig. 2. $\delta^{13} \mathrm{C}$ and $\delta^{18} \mathrm{O}$ isotope ratios of the investigated materials from Hole $418 \mathrm{~A}$ as a function of depth. 
Table 1. $\mathrm{CO}_{2}$ content and the isotopic composition of oxygen and carbon for all investigated samples

\begin{tabular}{|c|c|c|c|c|c|c|}
\hline \multicolumn{2}{|c|}{$\begin{array}{l}\text { DSDP Sample Designation } \\
\text { (Core-Section, Interval) }\end{array}$} & Material & $\underset{(\mathrm{m})}{\text { Depth }}$ & $\begin{array}{l}\mathrm{CO}_{2} \\
(\%)\end{array}$ & $\delta^{13} \mathrm{C}_{\text {PDB }}$ & $\delta^{18} \mathrm{O}_{\mathrm{PDB}}$ \\
\hline $\begin{array}{l}15-1 \\
15-1 \\
17-1 \\
18-1 \\
20-2 \\
24-1 \\
26-1 \\
26-4 \\
27-1 \\
30-1 \\
30-1 \\
36-4 \\
37-1 \\
37-1 \\
37-1 \\
38-5 \\
40-2 \\
41-4 \\
43-3 \\
44-3 \\
45-3 \\
45-4 \\
45-4 \\
46-5 \\
48-2 \\
48-5 \\
49-3 \\
50-2 \\
50-3 \\
51-4 \\
52-1 \\
52-4 \\
54-2 \\
54-2 \\
55-3 \\
56-6 \\
57-2 \\
59-2 \\
60-1 \\
62-3 \\
63-2 \\
63-3 \\
64-4 \\
65-4 \\
66-5 \\
66-c c \\
68-3 \\
69-1 \\
69-1 \\
69-4 \\
69-5 \\
69-6 \\
70-1 \\
70-4 \\
70-5 \\
70-5 \\
71-3 \\
73-2 \\
74-1 \\
74-6 \\
76-2 \\
77-2 \\
77-2 \\
77-3 \\
78-5 \\
79-5 \\
80-4 \\
81-4 \\
83-1 \\
83-4 \\
85-1 \\
85-5 \\
85-6 \\
85-7 \\
86-3 \\
?\end{array}$ & $\begin{array}{r}17-19 \\
21-22 \\
101-103 \\
38-40 \\
20-22 \\
95-97 \\
91-93 \\
59-61 \\
36-38 \\
63-65 \\
118-120 \\
10-12 \\
66-68 \\
66-68 \\
66-68 \\
119-121 \\
102-104 \\
32-34 \\
66-68 \\
54-56 \\
118-120 \\
22-30 \\
36-40 \\
62-64 \\
132-134 \\
21-23 \\
\text { cc } \\
29-32 \\
32-34 \\
69-71 \\
98-100 \\
20-25 \\
31-33 \\
45-48 \\
12-14 \\
135-137 \\
80-82 \\
132-134 \\
18-20 \\
87-90 \\
43-45 \\
109-111 \\
21-23 \\
79-82 \\
244-248 \\
25-29 \\
19-21 \\
118-122 \\
118-122 \\
100-105 \\
90-95 \\
64-66 \\
83-87 \\
108-111 \\
9-13 \\
93-95 \\
120-124 \\
137-140 \\
12-14 \\
85-86 \\
33-36 \\
42-44 \\
82-44 \\
117-120 \\
65-67 \\
22-26 \\
136-140 \\
144-147 \\
60-63 \\
146-148 \\
120-122 \\
127-131 \\
86-88 \\
144-147 \\
?\end{array}$ & $\begin{array}{l}\text { Sediment } \\
\text { Carbonate + Sediment } \\
\text { Basalt } \\
\text { Basalt } \\
\text { Basalt } \\
\text { Basalt } \\
\text { Basalt } \\
\text { Basalt + Carbonate } \\
\text { Basalt } \\
\text { Basalt } \\
\text { Basalt + Carbonate } \\
\text { Basalt } \\
\text { Carbonate } \\
\text { Carbonate } \\
\text { Carbonate } \\
\text { Basalt } \\
\text { Basalt + Carbonate } \\
\text { Basalt } \\
\text { Basalt } \\
\text { Basalt } \\
\text { Basalt } \\
\text { Basalt } \\
\text { Basalt + Carbonate } \\
\text { Basalt } \\
\text { Basalt } \\
\text { Basalt } \\
\text { Basalt } \\
\text { Basalt } \\
\text { Basalt } \\
\text { Basalt } \\
\text { Basalt } \\
\text { Basalt + Carbonate } \\
\text { Basalt } \\
\text { Basalt } \\
\text { Basalt } \\
\text { Basalt } \\
\text { Basalt } \\
\text { Basalt } \\
\text { Basalt } \\
\text { Basalt + Carbonate } \\
\text { Basalt + Carboante } \\
\text { Basalt } \\
\text { Basalt + Carbonate } \\
\text { Basalt + Carbonate } \\
\text { Basalt } \\
\text { Basalt } \\
\text { Basalt } \\
\text { Basalt } \\
\text { Basalt + Carbonate } \\
\text { Sediment } \\
\text { Basalt + Pyrite } \\
\text { Basalt + Pyrite } \\
\text { Basalt + Pyrite } \\
\text { Basalt } \\
\text { Basalt } \\
\text { Basalt } \\
\text { Basalt } \\
\text { Basalt + Carbonate } \\
\text { Basalt + Carbonate } \\
\text { Basalt } \\
\text { Basalt } \\
\text { Basalt + Carbonate } \\
\text { Carbonate } \\
\text { Basalt } \\
\text { Basalt } \\
\text { Basalt } \\
\text { Basalt } \\
\text { Basalt } \\
\text { Basalt } \\
\text { Basalt } \\
\text { Basalt } \\
\text { Basalt } \\
\text { Basalt } \\
\text { Basalt } \\
\text { Basalt + Carbonate }\end{array}$ & $\begin{array}{l}320.2 \\
320.2 \\
333.5 \\
339.4 \\
358.7 \\
377.0 \\
385.4 \\
301.1 \\
393.9 \\
415.1 \\
415.6 \\
471.6 \\
476.7 \\
476.7 \\
476.7 \\
486.7 \\
499.2 \\
503.3 \\
520.2 \\
529.1 \\
538.7 \\
539.2 \\
539.4 \\
550.1 \\
564.3 \\
567.7 \\
573.6 \\
575.3 \\
576.8 \\
588.1 \\
593.0 \\
596.9 \\
612.8 \\
613.0 \\
623.5 \\
638.7 \\
641.3 \\
660.2 \\
667.2 \\
689.9 \\
691.9 \\
694.1 \\
700.2 \\
705.9 \\
712.6 \\
722.1 \\
732.3 \\
734.8 \\
734.8 \\
740.6 \\
741.8 \\
742.7 \\
744.0 \\
748.8 \\
749.2 \\
750.0 \\
756.9 \\
767.7 \\
774.4 \\
782.7 \\
788.9 \\
795.0 \\
795.0 \\
796.9 \\
809.6 \\
819.1 \\
826.7 \\
836.9 \\
842.0 \\
845.6 \\
851.5 \\
857.2 \\
859.3 \\
859.9 \\
864.0 \\
?\end{array}$ & $\begin{array}{r}\text { n.d. } \\
\text { n.d. } \\
0.33 \\
0.34 \\
0.77 \\
0.45 \\
0.93 \\
6.76 \\
2.47 \\
0.86 \\
24.51 \\
0.32 \\
\\
\\
0.60 \\
6.07 \\
0.45 \\
0.94 \\
0.69 \\
0.26 \\
\text { n.d. } \\
1.33 \\
2.70 \\
2.67 \\
1.35 \\
0.30 \\
0.23 \\
0.99 \\
0.30 \\
0.58 \\
17.65 \\
0.20 \\
0.70 \\
0.47 \\
0.71 \\
\text { n.d. } \\
0.63 \\
0.28 \\
1.80 \\
8.23 \\
0.16 \\
1.20 \\
12.97 \\
0.86 \\
0.86 \\
1.09 \\
0.72 \\
4.38 \\
23.50 \\
\text { n.d. } \\
0.34 \\
1.43 \\
0.87 \\
0.64 \\
0.75 \\
1.47 \\
1.33 \\
15.77 \\
0.18 \\
0.75 \\
3.87 \\
0.76 \\
1.10 \\
0.41 \\
1.05 \\
0.10 \\
0.73 \\
0.81 \\
0.21 \\
5.12 \\
\text { n.d. } \\
0.81 \\
6.90 \\
0.70\end{array}$ & 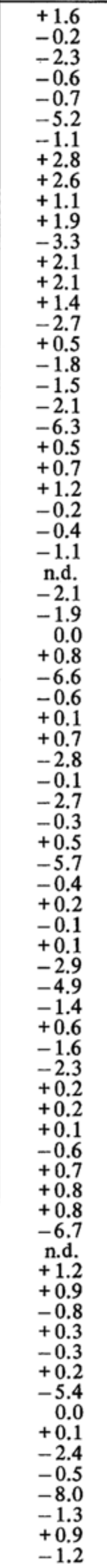 & $\begin{array}{r}-1.3 \\
-2.8 \\
-9.6 \\
-5.2 \\
-2.0 \\
-8.2 \\
-4.0 \\
-1.7 \\
-2.6 \\
-5.2 \\
-4.7 \\
-10.5 \\
-5.3 \\
-5.5 \\
-6.1 \\
-10.3 \\
-1.1 \\
-7.0 \\
-3.2 \\
-7.5 \\
-9.7 \\
-1.1 \\
-2.7 \\
-1.4 \\
-2.5 \\
-3.5 \\
-6.3 \\
n . d .\end{array}$ \\
\hline
\end{tabular}


carbonates occurring in the studied deep sea basalts would have resulted from cold seawater interaction. When studying in detail the data, a systematic distinction between two groups can be shown. The carbonates and the carbonate rich basalts display a trend which is different from that of the "fresh" basalts when all samples are plotted as a function of $\delta^{13} \mathrm{C}$ versus $\delta^{18} \mathrm{O}$ (see Fig. 3).

The "fresh" basalts (filled symbols) show a decrease in $\delta^{13} \mathrm{C}$ with decreasing $\delta^{18} \mathrm{O}$. The carbonates and the carbonate rich basalts show only a decrease in $\delta^{18} \mathrm{O}$ without a simultaneous decrease in $\delta^{13} \mathrm{C}$ which only varies about the mean value of normal marine carbonate. The effect observed in the "fresh" basalts can either be due to an equilibrium fractionation of both isotopic species at lower temperatures or to varying admixtures of secondary marine carbonates to a primary magmatic carbonate.

To produce isotope ratios as those observed in the carbonate rich basalts and the separated carbonates a larger carbon reservoir has to be assumed which could correspond to seawater. It seems that an alteration process accompanied by the formation of secondary marine carbonates affected most of the samples, even those

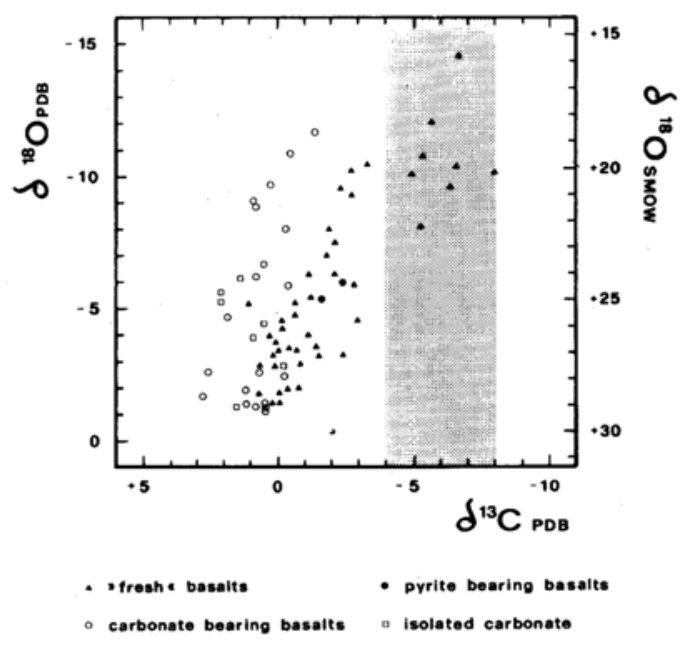

Fig. 3. $\delta^{13} \mathrm{C}$ versus $\delta^{18} \mathrm{O}$ of the investigated samples (the shaded area indicates the range of the assumed primary carbon).

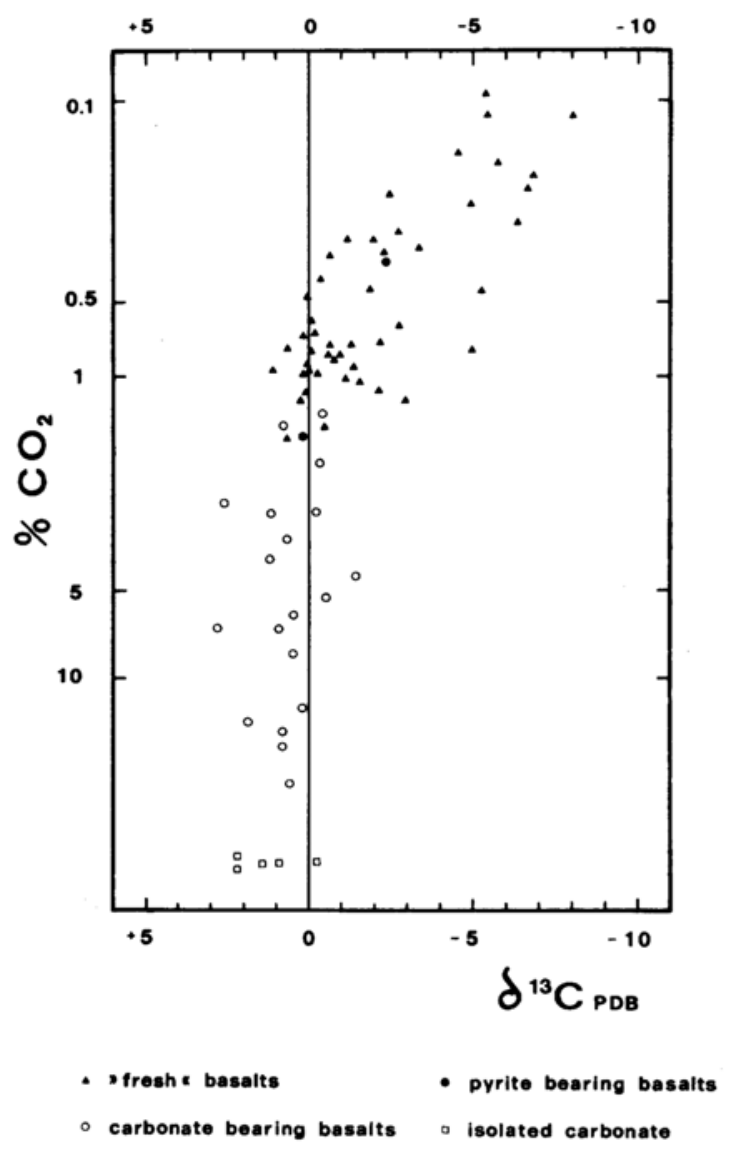

Fig. 4. Carbonate content $\left(\% \mathrm{CO}_{2}\right)$ in relation to the carbon isotope composition.

which were considered to be "fresh".

The fact that primary carbonate carbon unaffected by secondary processes is present in some of the basalts is indicated in Fig. 4 which shows the relationship between the $\delta^{13} \mathrm{C}$ values and the $\mathrm{CO}_{2}$ content. In a large range of carbonate content the carbon isotope values are scattered about the value of marine carbonate carbon. With decreasing carbonate content, the almost vertical trend turns toward isotopically lighter carbon at a carbonate content of about $1 \% \mathrm{CO}_{2}$. The lower the carbonate content, the lighter are the carbon isotope ratios until they reach values of -4 to $-8 \%$.

These values are in the same range as in carbonatites, volcanic gases and $\mathrm{CO}_{2}$ inclusions in oceanic basalts (TAYLOR et al., 1967; DEINES, 
1970; Pineau et al., 1976; Puchelt and HUBBERTEN, 1980), all of which are assumed to represent primary carbon. The preservation of such primary carbonate was assumed by JAVOY and Fouillac (1980) in some of the samples they analyzed from Holes 417A and 417D of Leg 51, DSDP.

Due to a low temperature alteration resulting, among other authigenic products, in the formation of seawater-derived carbonates a progressive increase in carbonate content up to about $1 \% \mathrm{CO}_{2}$ will produce a gradual enrichment in ${ }^{13} \mathrm{C}$. Assuming $\delta^{13} \mathrm{C}$ values of -6 and $0 \%$ for primary and secondary carbonates, respectively, $\delta^{13} \mathrm{C}$ of $-0.6 \%$ is expected when $0.2 \% \mathrm{CO}_{2}$ increases to $1 \%$ by addition of secondary carbonate.

Compared with the alteration of terrestrial basalts, seawater alteration of oceanic basalts produces a different shift of the primary carbon isotope composition. Terrestrial basalts are affected by solutions containing carbon species which can be derived from various sources: air $\mathrm{CO}_{2}$, dissolved $\mathrm{HCO}_{3}$, organogenically derived $\mathrm{CO}_{2}$, etc. The result of this alteration will be a shift to lighter or to heavier values. The widely scattered values which have been reported by O'NeIL et al. (1970) and HoEFs (1973) can partly be explained by such mechanisms.

When alteration by cold seawater takes place, the carbonate carbon isotope composition can only be shifted toward heavier values. No lighter carbonate can therefore be formed through submarine alteration processes but can only be of primary origin. Light carbon isotope values (to the $-25 \%$ range) as observed by O'NeIL et al. (1970) and HoEFs (1973) in carbonate bearing terrestrial basalts were not measured in the investigated oceanic basalts.

The alteration mechanisms of oceanic basalts and the fact that light isotope values are found in carbonate poor basalts lead to the conclusion that traces of primary carbonate carbon with an isotopic ratio from -4 to $-8 \%$ are present in these carbonate-poor basalts.

Acknowledgements-This study was suggested by Prof.
Dr. H. PUCHELT, Karlsruhe who made valuable suggestions during the investigations and writing up of the manuscript. Drs. J. HoEFS, Göttingen and J. HONNOREZ, Miami critically reviewed the manuscript. The investigations were supported by a grant of the Deutsche Forschungsgemeinschaft, Bonn.

I want to thank all individuals and institutions which thus contributed to the investigations.

\section{REFERENCES}

CRAIG, H. (1953) Isotopic standards for carbon and oxygen and correction factors for mass-spectrometric analysis of carbon dioxide. Geochim. Cosmochim. Acta 12, 133-149.

DEINES, P. (1970) The carbon and oxygen isotopic composition of carbonates from the Oka carbonatite complex, Quebec, Canada. Geochim. Cosmochim. Acta 34, 1199-1225.

EmmermanN, R. and PUChelt, H. (1980) Major and trace element chemistry of basalts from Holes 417D and 418A, Deep Sea Drilling Project Legs 51-53. In DONNELly, T., FRANCHETEAU, J., BRYAN, W., RobinSON, P., Flower, M., SAliSBURY, M., et al., Initial Repts. Deep Sea Drilling Project, 51, 52, 53, Part 2; Washington (U.S. Government Printing Office), 987-1000.

Flower, M. F. J., OHNMACHT, W., ROBINSON, P. T., MARINER, G. F. and SCHMINCKE, H.-U. (1980) Lithologic and chemical stratigraphy at Deep Sea Drilling Project Sites 417 and 418. In DONNELLY, T., Francheteau, J., BRyan, W., Robinson, P., FlOWER, M., SAlisbURY, M., et al., Initial Repts. Deep Sea Drilling Project, 51, 52, 53, Part 2; Washington (U.S. Government Printing Office), 939-956.

HOEFS, J. (1965) Ein Beitrag zur Geochemie des Kohlenstoffs in magmatischen und metamorphen Gesteinen. Geochim. Cosmochim. Acta 29, 399428 .

HOEFS, J. (1973) Ein Beitrag zur Isotopengeochemie des Kohlenstoffs in magmatischen Gesteinen. Contrib. Mineral. Petrol. 41, 277-300.

HUMPHRIS, S. E., THOMPSON, R. N. and MARINER, G. F. (1980) The mineralogy and geochemistry of basalt weathering, Holes $417 \mathrm{~A}$ and $418 \mathrm{~A}$. In DONNElly, T., FrancheteaU, J., BRYAN, W., ROBINSON, P., FlOWER, M., SALISBURY, M., et al., Initial Repts. Deep Sea Drilling Project, 51, 52, 53 Part 2: Washington (U.S. Government Printing Office), 1201-1217.

JAVOY, M. and FouIllaC, A. M. (1980) Stable isotope ratios in Deep Sea Drilling Project Leg 51 basalts. In DONNELlY, T., FRANCHETEAU, J., BRYAN, W., ROBINSON, P., FLOWER, M., SALISBURY, 
M., et al., Initial Repts. Deep Sea Drilling Project, 51, 52, 53 Part 2: Washington (U.S. Government Printing Office), 1153-1157.

KEITH, M. L. and WEBER, J. N. (1964) Isotopic composition and environmental classification of selected limestones and fossils. Geochim. Cosmochim. Acta 28, 1787-1816.

MCCREA, J. M. (1950) The isotopic chemistry of carbonates and a palaeotemperature scale. J. Chem. Phys. 18, 849-864.

O'NEIL, J. R., HEDGE, C. E. and JACKSON, E. D. (1970) Isotopic investigations of xenoliths and host basalts from the Honolulu volcanic series. Earth Planet. Sci. Let. 8, 253-257.

PineaU, F., JavoY, M. and BotTinga, Y. (1976) ${ }^{13} \mathrm{C} /{ }^{12} \mathrm{C}$ ratios of rocks and inclusions in popping rocks of the Mid-Atlantic Ridge and their bearing on the problem of isotopic composition of deep-seated carbon. Earth Planet. Sci. Let. 29, 413-421.

Puchelt, H. and Hubberten, H.-W. (1980) Vul- kanogenes Kohlendioxid: Aussagen zur Herkunft aufgrund von Isotopenuntersuchungen. ZFI Mitt. 30, Leipzig, 198-210.

RöSler, H.-J., Nestler, P., MUCKe, D. and Dietze, W. (1977) Zur Herkunft der Karbonate in basischen Gesteinen aufgrund von ${ }^{18} \mathrm{O}$ und ${ }^{13} \mathrm{C}$ - Isotopenuntersuchungen. Z. angew. Geol. 23, 390-393.

Robinson, P. T., Flower, M. F. J., SWANSON, D. A. and STAUDIGEL, H. (1980) Lithology and eruptive stratigraphy of Cretaceous oceanic crust, Western Atlantic Ocean. In DONNELlY, T., FranCHETEAU, J., BRYAN, W., ROBINSON, P., FlOWER, M., SALISBURY, M., et al., Initial Repts. Deep Sea Drilling Project, 51, 52, 53 Part 2: Washington (U.S. Government Printing Office), 1535-1555.

TAYLOR, H. P., FRECHEN, J. and DEGENS, E. T. (1967) Oxygen and carbon isotope studies of carbonatites from the Laacher See district, West Germany and the Alno district, Sweden. Geochim. Cosmochim. Acta 31, 407-430. 